\title{
ANALISIS STRUKTURAL DAN NILAI MORAL KUMPULAN CERPEN TUHAN BUAT VASTY SUNTINGAN ASEP SAMBODJA
}

\author{
Dedi Febriyanto $^{1^{*}}$, Suryani ${ }^{2}$ \\ Program Studi Pendidikan Bahasa dan Sastra Indonesia \\ STKIP Nurul Huda OKU Timur \\ dedifebri97@gmail.com \\ suryani@stkipnurulhuda.ac.id
}

\begin{abstract}
Abstrak
Penelitian ini bertujuan mendeskripsikan unsur-unsur intrinsik dan nilai moral yang terkandung dalam kumpulan cerpen Tuhan buat Vasty Suntingan Asep Sambodja. Penelitian ini dilatarbelakangi oleh keunikan cerpen yang peneliti temukan saat membacanya. Teori struktural yang digunakan adalah teori Nurgiantoro, sedangkan teori nilai moral yang digunakan adalah teori Suseno. Metode dalam penelitian ini adalah deskriptif kualitatif melalui pendekatan objektif. Teknik pengumpulan data menggunakan teknik simak dan teknik catat, sedangkan teknik analisis data menggunakan teknik analisis isi (content analysis). Analisis struktural dalam penelitian ini menekankan pada analisis unsurunsur intrinsik cerpen yang meliputi tema, tokoh, penokohan, latar, alur, sudut pandang, dan amanat. Unsur-unsur tersebut membentuk satu kesatuan yang utuh dalam mewujudkan nilai-nilai moral di dalamnya. Adapun nilai moral yang terkandung di dalam cerpen meliputi kepedulian sosial, toleransi, kejujuran, kesediaan bertanggung jawab, keberanian moral, religiositas, bekerja keras, dan optimisme.
\end{abstract}

Kata kunci: Struktural, nilai moral, Cerpen, Tuhan buat Vasty.

\section{PENDAHULUAN}

Karya sastra merupakan sebuah sistem yang terdiri dari unsur-unsur yang saling berhubungan dalam membentuk suatu kesatuan yang utuh. Hal ini senada dengan yang disampaikan oleh Pradopo (dikutip Jabrohim, 2015:69) yang mengatakan bahwa, "Karya sastra merupakan suatu struktur yang otonom yang dapat dipahami sebagai suatu kesatuan yang bulat dengan unsur-unsur pembangunnya yang saling berjalinan." Keutuhan unsur dalam karya sastra bukan hanya merupakan kumpulan benda yang berdiri sendiri, melainkan yang saling terkait. Artinya, untuk memahmi maknanya secara penuh, karya sastra harus dikaji berdasarkan strukturnya sendiri, terlepas dari latar belakang sejarah, keadaan sosial-budaya, dan perspektif dari penulis maupun pembacanya itu sendiri.

Cerpen adalah salah satu bentuk karya fiksi. Menurut Priyatni (2010:126), "Cerpen sesuai dengan namanya, memperlihatkan sifat yang serba pendek, baik peristiwa yang diungkapkan, isi cerita, jumlah pelaku, dan jumlah kata yang digunakan." Cerpen sebagai sebuah karya sastra cenderung kurang kompleks jika dibandingkan dengan karya sastra lain seperti novel. Cerpen biasanya memusatkan pada satu kejadian, beralur tunggal, serta memiliki cakupan waktu yang relatif singkat dan terbatas.

Sebagaimana yang telah disebutkan sebelumnya bahwa karya sastra merupakan sebuah sistem yang terdiri dari bagian-bagian yang saling berkaitan. Maka untuk mengetahui hubungan antar unsur dalam sebuah karya sastra, termasuk cerpen, kita perlu melakukan sebuah analisis terhadap karya sastra tersebut. Menganalisis sebuah karya sastra memerlukan teori khusus pengkajian, salah satunya adalah kajian struktural. Kajian struktural merupakan salah satu kajian yang menitikberatkan pada pengkajian unsur-unsur pembangun karya sastra itu sendiri. Dengan kata lain, melalui analisis struktural berarti sebuah cerpen akan dianalisis dengan menunjukkan hubungan-hubungan antar unsurnya. Unsur-unsur yang dimaksud adalah unsur internal, yaitu unsur-unsur yang terdapat di dalam cerpen itu sendiri. Unsurr-unsur internal meliputi tema, tokoh, penokohan, alur, latar, sudut pandang, serta amanat.

Selain menganalisis struktur, hal yang tak kalah penting yang harus dianalisis dalam sebuah cerpen adalah nilai moral. Moral merupakan aspek penting yang harus ada di dalam sebuah karya sastra, termasuk cerpen. Cerpen sebagai karya sastra tidak hanya berfungsi sebagai sarana hiburan 
semata, melainkan juga sarana yang digunakan untuk menyampaikan pesan-pesan, yaitu berupa nilai-nilai moral yang digambarkan pengarang melalui berbagai cara. Melalui nilai moral tersebut, pembaca dapat memahami sudut pandang penulis terhadap nilai-nilai kehidupan. Hal tersebut didukung oleh pendapat Nurgiyantoro (2015: 430) yang mengatakan, "Moral dalam karya sastra biasanya mencerminkan pandangan hidup pengarang yang bersangkutan. Pandangannya tentang nilai-nilai kebenaran, dan hal itulah yang ingin disampaikannya kepada pembaca." Setelah membaca cerpen, diharapkan pandangan tersebut sampai kepada pembaca.

Adapun cerpen yang menjadi kajian peneliti adalah kumpulan cerpen Tuhan Buat Vasty suntingan Asep Sambodja yang terdiri atas tiga bagian, yakni, Tuhan Buat Vasty karya Dahlia Isnaini, Ibu karya Tyagita Silka Hapsari, dan Proteumus dan Clasius karya Aryo Wasisto. Ada beberapa alasan mengapa ketiga cerpen ini menjadi pilihan dan layak untuk diteliti.

Pertama, semua cerita yang diangkat di dalam ketiga cerpen tersebut selalu melibatkan pemuda. Hal ini bisa dibuktikan dengan adanya tokoh Vasty dalam cerpen Tuhan buat Vasty yang merupakan seorang siswa SMA/sederajat. Tokoh Silka dalam cerpen Ibu serta Protemus dan Claius dalam cerpen Protemus dan Claius yang merupakan seorang mahasiswa. Membaca ketiga cerpen tersebut akan menimbulkan kesan bahwa ada pesan-pesan khusus untuk para pemuda tentang cara menyikapi setiap persoalan hidup.

Kedua, cerita dalam ketiga cerpen tersebut selalu diakhiri dengan kematian sang tokoh utama. Hal ini tergolong langka dan unik karena umumnya akhir cerita sebuah cerpen selalu menonjolkan ketokohan yang kuat dari sang tokoh utama. Umumnya akhir cerita sebuah cerpen selalu tentang perasaan, senang, gembira, sedih, tetapi tidak sampai membuat sang tokoh utama meninggal.

Ketiga, ketiga cerpen tersebut banyak mengandung nilai-nilai moral yang sangat cocok untuk diimplementasikan dalam kehidupan saat ini, khususnya untuk para pemuda. Meskipun di dalam setiap cerpen mengandung nilai moral, namun nilai moral dalam ketiga cerpen yang peneliti analisis mengandung pesan-pesan moral yang menyasar kepada para pemuda sebagai generasi penerus bangsa. Pesan-pesan tersebut berkaitan dengan bagaimana kita memperlakukan orangtua, bagaimana cara menghadapi sebuah perbedaan, dan lain sebagainya. Intinya, ketiga cerpen yang peneliti pilih memiliki relevansi yang kuat dengan keadaan para pemuda saat ini.

Secara garis besar, cerpen Tuhan buat Vasty menceritakan tentang permasalahan keluarga yang dipicu oleh pernikahan beda agama. Permasalahan yang muncul berakibat buruk bagi Vasty sang anak. Cerpen lbu menceritakan tentang seorang ibu yang menderita penyakit kanker. Segala macam usaha telah dilakukan, namun penyakitnya justru semakin parah hingga berakhir dengan kematian. Sedangkan cerpen Protemus dan Claius mengisahkan tentang dua laki-laki bersaudara yang terlahir abnormal karena kedua kepalanya menyatu. Keduanya dituntut untuk selalu kompak dalam melakukan segala sesuatu.

\section{METODE PENELITIAN}

Metode yang digunakan dalam penelitian ini adalah metode deskriptif analisis. Metode deskriptif analisis adalah metode yang digunakan untuk menguraikan atau mendeskripsikan fakta-fakta yang kemudian disusul dengan analisis (Ratna, 2015:53). Metode ini digunakan karena penelitian ini bersifat studi pustaka, yang datanya berupa dokumen (buku kumpulan cerita pendek) dan bukan berupa angka-angka. Penelitian ini tidak terbatas hanya pada pengumpulan data saja, tetapi juga meliputi analisis dan interpretasi. Hasil yang diperoleh dalam penelitian ini berupa kutipan-kutipan data yang berisi tentang keterkaitan unsur-unsur intrinsik dan nilai-nilai moral dalam karya sastra yang menggunakan pendekatan objektif.

Adapun data dalam penelitian ini berupa kutipan-kutipan kalimat yang terdapat dalam kumpulan cerpen Tuhan Buat Vasty suntingan Asep Sambodja. Data tersebut selanjutkan akan dianalisis menggunakan teknik induktif. Menurut KBBI (2008:533), teknik induktif adalah teknik bersifat induksi yang berarti penarikan kesimpulan berdasarkan keadaan khusus untuk diperlakukan secara umum. Analisis data secara induktif digunakan karena proses induktif ini lebih mudah untuk menemukan kenyataan-kenyatan jamak yang terdapat dalam data dan dapat memperhitungkan nilai-nilai secara terbuka sebagai bagian struktur analitik.

\section{HASIL DAN PEMBAHASAN}

\section{Hasil}

Data dalam penelitian ini adalah kutipan-kutipan kalimat yang terkandung di dalam kumpulan cerpen Tuhan buat Vasty suntingan Asep Sambodja. Berdasarkan data-data yang telah dianalisis, dapat diketahui adanya keterkaitan yang erat antarunsur intrinsik cerpen. Unsur-unsur tersebut tidak dapat berdiri sendiri dalam melakasanakan fungsinya sebagai unsur sebuah cerita. Setiap unsur memiliki ketergantungan dan keterkaitan tak terpisahkan terhadap unsur-unsur lainnya. Unsur-unsur tersebut membentuk suatu jalinan utuh dalam memperlihatkan makna cerita yang hendak disampaikan pengarang. Melalui unsur struktural tersebut, tergambar pula nilai-nilai moral yang sangat elok diterapkan dalam kehidupan sehari-hari. Beberapa nilai moral yang tergambar di dalam

Dedi Febriyanto, Suryani 
ANALISIS STRUKTUR DAN NILAI MORAL KUMPULAN CERPEN.... $\mid 15$ novel di antaranya adalah religiositas, kejujuran, toleransi, kesediaan bertanggung jawab, dan bekerja keras.

\section{Pembahasan}

\section{Analisis Struktural Kumpulan Cerpen Tuhan buat Vasty Suntingan Asep Sambodja}

Berdasarkan kajian struktural, diketahui bahwa cerpen Tuhan buat Vasty Karya Dahlia Isnaini merupakan sebuah cerpen yang bertemakan curahan hati seorang anak tentang permasalahan keluarganya yang berbeda agama. Adapun untuk mewujudkan tema tersebut perlu melibatkan tokohtokoh cerita, yaitu Vasty sebagai tokoh utama, Rara, Ibu Rara, Bapak Rara, Kerabat Vasty, dan orangtua Vasty sebagai tokoh tambahan. Vasty sebagai tokoh utama memiliki karakter peduli dan lemah pendirian. Rara digambarkan sebagai sosok yang bijaksana dan peduli, begitupun dengan Ibu Rara. Bapak Rara tipikal orang yang santai, kerabat Vasty adalah sosok yang penuh tanggung jawab sedangkan orangtua Vasty memiliki keegoisan yang besar. Keberadaan tokoh tambahan dalam cerpen Tuhan buat Vasty sangat mempengaruhi jalan cerita. Hal ini dikarenakan tokoh-tokoh tambahan yang telah disebutkan memiliki hubungan tak terpisahkan dengan tokoh utama. Hal ini bisa dilihat pada kutipan berikut.

"Tadinya gue pikir gue masih bisa membujuk mereka supaya membatalkan perceraian mereka, tapi semalam mereka bertengkar lagi. Gue nggak tahu mesti gimana lagi, Ra! Gue nggak mau mereka cerai. Cuma mereka yang gue punya, Ra." Vasty berusaha menyeka air matanya."

(Sambodja, 2007:22)

Kutipan di atas jelas memperlihatkan keterkaitan antar unsur cerita yang begitu erat, mulai dari tokoh, tema, pengaluran, dan lain sebagainya.

Pengaluran dalam cerpen Tuhan buat Vasty menggunakan alur maju. Hal ini dikarenakan peristiwa yang diceritakan berjalan sesuai dengan urutan waktu (kronologis). Latar yang terdapat dalam cerpen Tuhan buat Vasty meliputi latar tempat, latar waktu, dan latar sosial. Sudut pandang yang digunakan pengarang dalam cerpen Tuhan buat Vasty adalah sudut pandang personal pertama "Aku" yang diperankan oleh tokoh tambahan. Tokoh tambahan yang dimaksud adalah Rara yang merupakan sahabat dekat Vasty. Adapun amanat yang disampaikan cerpen Tuhan buat Vasty meliputi anjuran untuk bersikap jujur, bersungguh-sungguh dalam beragama, ketegasan dalam bersikap, bersyukur kepada Allah, dan selalu mempertimbangkan segala sesuatunya sebelum mengambil suatu keputusan. Unsur-unsur tersebut membentuk suatu hubungan yang utuh dalam mewujudkan cerita yang berkualitas. Hal ini bisa dilihat pada kutipan berikut.

Hujan turun sangat deras ketika bel sekolah berbunyi. Aku segera membereskan alat tulisku dan berjalan keluar kelas.

"Ra, bawa payung nggak?" teriak Vasty ketika aku baru keluar dari kelas. Rupanya kelasnya Vasty sudah bubar dari tadi. Kelas IPS memang selalu selesai lebih awal, tidak seperti kelas IPA-ku yang baru selesai tepat ketika bel dibunyikan.

Tiba-tiba mata Vasty berkaca-kaca.

(Sambodja, 2007:19)

"Ra, gue bingung...," ia menutupi wajahnya dengan kedua tangannya. Aku semakin bingung. Kenapa sih Vasty?

"Bokap Nyokap gue mau cerai. Lo tahu kan selama ini agama mereka beda. Sekarang mereka tanya masalah pilihan agama gue. Gue nggak mau bikin salah satu dari mereka sedih atau kecewa.

(Sambodja, 2007:22)

Malamnya aku menunggu telepon dari Vasty sampai satu jam. Handphone-nya tidak aktif waktu kuhubungi. Begitu juga waktu aku mencoba menelepon ke rumahnya. Tidak ada yang menjawab teleponku.

(Sambodja, 2007:26)

Esoknya aku tidak bertemu Vasty di sekolah. Waktu ku tanyakan kepada teman-teman sekelasnya, tidak ada seorangpun yang tahu kabarnya. Begitu juga pihak sekolah.

(Sambodja, 2007:27)

Sorenya aku pulang sekolah dengan masih memikirkan Vasty. Sesampainya di rumah, ibu memelukku sambil berbisik.

"Ra, Vasty meninggal satu jam yang lalu."

Dedi Febriyanto, Suryani 
Aku diam dan menangis. Badanku lemas mendengar berita tersebut.

Ibu yang menerima telepon dari salah satu kerabat Vasty. Menurut kerabat Vasty, Vasty dan kedua orangtuanya mengalami kecelakaan mobil dua jam yang lalu. Mereka dalam perjalanan menuju pengadilan negeri ketika kecelakaan itu terjadi. Kedua orangtua Vasty sekarang masih dalam keadaan kritis, sedangkan Vasty meninggal dalam perjalanan menuju runah sakit karena kehabisan darah.

(Sambodja, 2007:27)

Kertas post-it itu ditemukan di atas tempat tidur Vasty. Sepertinya ia sudah mempunyai firasat atas kejadian yang akan menimpanya. Esok paginya aku kembali menerima kabar duka. Kedua orangtua Vasty gagal melewati masa kritis. Selang lima menit ayahnya juga meninggal. Sepertinya Tuhan mengabulkan doa Vasty. Kini Vasty bia terus berada di dekat Tuhan dan kedua orangtuanya.

(Sambodja, 2007:27-28)

Kutipan di atas secara berturut-turut menjelaskan tentang alur penceritaan dalam cerpen Tuhan buat Vasty. Secara umum, cerpen-cerpen lainnya juga memiliki pola pengembangan alur yang serupa, Alur dimulai dari tahap orientasi dan diakhiri resolusi. Selain menggambarkan pengaluran cerita, kutipan di atas juga menggambarka hubungan unsur-unsur cerita yang lainnya, mulai dari tokoh dan penokohan, sudut pandang dan lain sebagainya.

Cerpen Ibu karya Tyagita Silka Hapsari merupakan cerpen yang mengangkat tema tentang perjuangan seorang ibu melawan penyakit kanker yang dideritanya. Adapun untuk mewujudkan tema tersebut diperlukan tokoh-tokoh di dalamnya. Tokoh di dalam cerpen lbu di antaranya adalah lbu sebagai tokoh utama, Silka dan ayah Silka, Om Bagus, Tante dan Kakak sepupu Silka yang merupakan tokoh tambahan. Ibu Silka digambarkan sebagai sosok wanita yang kuat dan ceria. Silka sendiri digambarkan sebagai seorang anak yang bertanggung jawab dan sangat menyayangi ibunya. Sedangkan ayah, tante, dan kakak sepupu Silka merupakan sosok yang penuh rasa tanggung jawab. Semua tokoh tambahan sangat mempengaruhi pengaluran cerita dan pembentukan tema. Hal ini dikarenakan tokoh-tokoh tersebut merupakan keluarga dekat dari sang tokoh utama. Berikut kutipannya:

Ibuku sakit. Sejak tahun 2001 payudara kirinya digerogoti sel-sel kanker yang ganas.

(Sambodja, 2007:38)

Sang ibu pun tak pernah berhenti berusaha. Keluarga besarnya pun telah mengeluarkan usaha maksimal demi mewujudkan kesembuhan sang lbu. Meski bukan dari keluarga kaya, pihak keluarga tetap memberikan yang terbaik demi kesembuhan sang lbu. Hal ini dibuktikan pada kutipan berikut.

Ibu trauma pada rumah sakit karena mbah kakung meninggal di sana. Ibu memilih pengobatan alternatif. Apapun jenisnya, ibu mencobanya tanpa henti. Kami tidak kaya, namun rupiah tidak menjadi masalah. Kesembuhan ibu adalah yang paling utama.

Ibu tidak berhenti berusaha, sel-sel kanker pun tidak berhenti bekerja.

(Sambodja, 2007:39)

Pengaluran dalam cerpen Ibu menggunakan alur maju. Dikatakan alur maju karena peristiwa yang diceritakan berjalan sesuai dengan urutan waktu (kronologis). Latar yang terdapat di dalam cerpen Ibu meliputi latar tempat, latar waktu, dan latar sosial. Sudut pandang yang digunakan pengarang dalam cerpen Ibu adalah sudut pandang personal pertama "Aku" yang diperankan oleh tokoh tambahan. Tokoh tambahan yang dimaksud adalah Silka yang merupakan anak dari sang tokoh utama. Adapun amanat yang disampaikan dalam cerpen lbu meliputi anjuran untuk senantiasa berusaha dan berdoa untuk merubah keadaan, menjadi pribadi yang memliki kepedulian terhadap sesama, rela terhadap semua ketetapan Tuhan yang Maha Kuasa, serta anjuran untuk selalu menyayangi dan berbakti kepada orangtua. Unsur-unsur di atas membentuk suatu hubungan yang saling mengikat dalam mewujudkan sebuah cerita yang baik dan menarik untuk dinikmati.

Selama perjalanan aku hanya bisa berdoa, Tuhan, kalau memang kau akan mengambil lbu, biarkan aku melihatnya untuk terakhir kali dalam keadaan hidup. Jangan ambil ibu sekarang, Tuhan, tunggulah aku satu jam lagi.

(Sambodja, 2007: 42)

Kutipan di atas menggambarkan harapan Silka yang begitu besar kepada Tuhan agar jangan mengambil nyawa Ibunya dahulu sebelum Silka menemuinya untuk yang terakhir kali. Silka menyampaikan permohonannya tersebut setelah mendapatkan kode dari sang ayah bahwa lbunya 
ANALISIS STRUKTUR DAN NILAI MORAL KUMPULAN CERPEN.... $\mid 17$ telah dibawa pulang karena kondisinya yang semakin memburuk. Selain itu, pada kutipan di atas juga tergambar keterkaitan antar unsur cerita. Unsur-unsur cerita tersebut meliputi pengaluran, sudut pandang, dan amanat.

Cerpen Protemus dan Claius mengangkat tema tentang harapan dua saudara kembar yang terlahir abnormal (kepala menyatu) untuk dapat menjalani kehidupannya dengan normal. Adapun untuk mewujudkan tema tersebut diperlukan tokoh-tokoh di dalamnya. Tokoh di dalam cerpen Ptotemus dan Claius meliputi dua tokoh utama dan tiga tokoh tambahan. Protemus dan Claius merupakan tokoh utama dalam cerpen ini. Adapun tokoh tambahan di dalam cerpen ini adalah Marnia Redha, Tuan Balgan, dan Nyonya Valon. Protemus digambarkan sebagai sosok yang ramah, optimis dan bijaksana. Claius digambarkan sebagai sosok yang pemalu, berjiwa besar dan pesimis. Redha digambarkan sebagai wanita pecinta anggrek yang sederhana. Tuan Balgan digambarkan sebagai sosok yang peduli terhadap sesama. Sedangkan Nyonya Valon digambarkan sebagai sosok yang suka memberi. Tema dan hubungan antar unsurnya bisa dilihat pada kutipan berikut.

"Dan, kau lelaki yang kasar! Nilai bahasa dan mengarangmu tidak akan pernah mendapat hasil yang memuaskan jika kau tidak mencuri otakku. Daya ingatmu seperti balon yang mengampul ke langit! Dan, kau selalu saja bangga dengan kemampuan berhitungmu! Kau tidak sadar!"

"Kita buktikan setelah kita berpisah!"

"Aku sangat menunggunya!"

(Sambodja, 2007:110-111)

Mereka benar-benar terpaku dalam kebisuan. Tanpa tawa. Claius membaca buku kesayangannya, sementara Protemus menulis sajak yang sudah menjadi buku. Satu harapan yang mereka inginkan adalah hanya bebas dari ikatan.

(Sambodja, 2007:111)

Berdasarkan kutipan-kutipan bercetak tebal di atas, jelas terlihat bahwa Protemus dan Claius sangat menginginkan kehidupan yang normal. Terbebas dari keterikatan yang menjadikan mereka laksana monster. Hal itu dikarenakan tidak mudah menjalani kehidupan dengan kepala menyatu. Kemana-mana selalu bersama, melakukan segala sesuatu bersama-sama. Keadaan inilah yang kemudian sering menimbulkan cekcok atau konflik antara Protemus dan Claius.

Pengaluran dalam cerpen Protemus dan Claius menggunakan alur maju. Hal ini dikarenakan semua cerita peristiwa yang terdapat di dalam cerpen berjalan sesuai dengan urutan waktu (kronologis). Latar yang terdapat di dalam cerpen Protemus dan Claius meliputi latar tempat, latar waktu, dan latar sosial. Sudut pandang yang digunakan pengarang dalam cerpen Protemus dan Claius adalah sudut pandang persona ketiga 'Dia' dengan menggunakan variasi kata ganti 'Mereka', 'Ia', atau nama orang. Adapun amanat yang disampaikan dalam cerpen ini meliputi anjuran untuk membiasakan diri dalam berbuat baik, menghindari sikap tergesa-gesa, menghargai kebaikan dan perasaan orang lain, serta jangan melakukan tindakan-tindakan bodoh yang dapat merugikan diri sendiri dan orang lain. Unsur-unsur tersebut membentuk suatu hubungan yang harmonis dalam mewujudkan sebuah cerita yang bernilai sastra tinggi. Berikut ini merupakan kutipan sudut pandang yang juga memiliki keterkaitan dengan latar cerita, sudut pandang, dan amanat.

Kalender menunjukkan tanggal 9 September. Mereka telah menghitung hari dengan melingkari angka-angka. Sebulan lagi Persiapan mereka menuju operasi pembelahan kepala. Sewaktu-waktu pertanyaan batin perihal kematian mengitari kepala mereka. Protemus dan Claius selalu mengendapkan pertanyaan-pertanyaan itu dan melelehkannya dalam keoptimisan.

(Sambodja, 2007:105)

Pengarang melalui kutipan di atas juga menjelaskan lebih jauh tentang kekhawatiran dua saudara kembar akan bayang-bayang kematian yang sewaktu-waktu datang menghampirinya setelah operasi. Hal ini dikarenakan mereka sudah mengetahui bahwa kematian adalah resiko terbesar yang akan terjadi ketika operasi dilaksanakan. Meskipun demikian, mereka selalu membangun keoptimisan yang kuat dalam diri.

\section{Analisis Nilai Moral Kumpulan Cerpen Tuhan buat Vasty Suntingan Asep Sambodja}

Nilai-nilai moral yang terkandung di dalam kumpulan cerpen Tuhan buat Vasty meliputi kepedulian sosial, kejujuran, toleransi, kesediaan bertanggung jawab, keberanian moral, dan religiositas, bekerja keras, optimisme, dan religiositas. Nilai-nilai moral yang terkandung di dalam cerpen-cerpen bisa diketahui melalui tingkah laku maupun gerak-gerik tokoh cerita, didukung oleh unsur-unsur cerita lainnya. Beberapa gambaran nilai moral dalam cerpen adalah sebagai berikut. 


\title{
1. Kepedulian Sosial
}

Kepedulian Sosial merupakan sikap dan tindakan yang selalu ingin memberi bantuan pada orang lain dan masyarakat yang membutuhkan. Dalam cerpen Tuhan buat Vasty, nilai moral tentang kepedulian sosial ditunjukkan oleh Vasty. Kepedulian sosial yang ditunjukkan oleh Vasty bisa dilihat pada kutipan berikut.

\begin{abstract}
"Tadinya gue pikir gue masih bisa membujuk mereka supaya membatalkan perceraian mereka, tapi semalam mereka bertengkar lagi. Gue nggak tahu mesti gimana lagi, Ra! Gue nggak mau mereka cerai. Cuma mereka yang gue punya, Ra." Vasty berusaha menyeka air matanya."
\end{abstract}

(Sambodja, 2007:22)

Pada kutipan di atas, jelas terlihat betapa Vasty sangat peduli terhadap keutuhan keluarganya. Vasty tidak mau jika orangtuanya harus berpisah karena perbedaan agama yang dianutnya. Oleh karena itu Vasty selalu membujuk orang tuanya agar orangtuanya membatalkan perceraiannya.

\section{Toleransi}

Toleransi merupakan sikap dan tindakan yang menghargai perbedaan agama, suku, etnis, pendapat, sikap, dan tindakan orang lain yang berbeda dari dirinya. Ada keunikan tersendiri berkaitan dengan toleransi yang disampaikan pengarang dalam cerpen ini. Keunikan tersebut terdapat pada satu poin toleransi yaitu cara pengarang menyampaikan nilai toleransi. Pada poin tersebut pengarang menyampaikannya dengan cara yang sebaliknya. Artinya pengarang dalam menyampaikan nilai toleransi justru melalui serangkaian peristiwa yang menggambarkan pelanggaran-pelanggaran terhadap batas toleransi itu sendiri. Nilai moral tentang toleransi yang terkandung di dalam cerpen ini terasa sangat kental. Ada beberapa poin yang menunjukkan nilai toleransi dalam cerpen Tuhan Buat Vasty. Poin-poin tersebut dijelaskan sebagai berikut.

\section{a. Pernikahan orangtua Vasty yang melanggar batas-batas toleransi sehingga melegalkan pernikahan beda agama.}

Berkaitan dengan pernikahan beda agama yang dilakukan orangtua Vasty bisa dilihat pada kutipan berikut:

"Bokap Nyokap gue mau cerai. Lo tahu kan selama ini agama mereka beda. Sekarang mereka tanya masalah pilihan agama gue. Gue nggak mau bikin salah satu dari mereka sedih atau kecewa.

(Sambodja, 2007:22)

Pada kutipan di atas, bisa diketahui bahwa pernikahan orangtua Vasty dilatarbelakangi oleh perbedaan agama antara keduanya. Cerita ini juga mengajarkan kepada kita bahwa sebaik apapun sikap toleransi, sikap tersebut tetap memiliki batasan-batasan yang tidak boleh dilanggar. Sebab jika batasan itu dilanggar akan dapat merugikan manusia itu sendiri.

Pernikahan beda agama di Indonesia memang tidak diatur secara tegas dalam undang-undang. Berkaitan dengan pernikahan beda agama, dalam Undang-undang perkawinan pasal 2 ayat 1 (dikutip Wahyuni) disebutkan, "Perkawinan adalah sah, apabila dilakukan menurut hukum masing-masing agamanya dan kepercayaannya itu." Berkaitan dengan pasal tersebut di atas, Hazairin (dikutip Wahyuni) mengatakan bahwa bagi orang Islam tidak ada kemungkinan untuk kawin dengan melanggar hukum agamnya sendiri. Demikian juga bagi orang Kristen, Hindu, atau Budha seperti yang dijumpai di Indonesia.

Sedangkan menurut agama Islam, pernikahan beda agama merupakan salah satu bentuk pernikahan yang terlarang. Hal ini senada dengan firman Allah dalam Al-Qur'an.

Dan janganlah kamu menikahi wanita-wanita musyrik sebelum mereka beriman. Sesungguhnya wanita budak yang mukmin lebih baik dari wanita musyrik, walaupun dia menarik hatimu. Dan janganlah kamu menikahkan orang-orang musyrik (dengan wanitawanita mukmin) sebelum mereka beriman. Sesungguhnya budak yang mukmin lebih baik dari orang musyrik, walaupun dia menarik hatimu. Mereka mengajak ke neraka, sedang Allah mengajak ke surga dan ampunan dengan ijin-Nya (QS. Al-Baqarah:221).

Berdasarkan penjelasan-penjelasan di atas, pernikahan beda agama di Indonesia sebenarnya adalah pernikahan yang tidak dilegalkan mengingat Indonesia berpegang pada prinsip "Ketuhanan yang Maha Esa". Artinya, semua warna negara wajib mempercayai tuhan yang satu, menjalankan dan meyakini petunjuk tuhan melalui aturan-aturan yang baku dan mengikat (agama). 
ANALISIS STRUKTUR DAN NILAI MORAL KUMPULAN CERPEN.... |19

\section{b. Rara tetap menjalin persahabatan dengan Vasty meski Rara sudah mengetahui bahwa Vasty beragama Kristen.}

Di dalam cerpen Tuhan buat Vasty diceritakan, Rara tidak mengetahui bahwa ternyata Vasty merupakan seorang Kristiani. Karena sepengetahuan Rara, Vasty adalah seorang yang beragama Islam.

"Kok bisa ya, Ra? Ibu kira selama ini agama Vasty Islam."

"Rara pikir juga begitu. Selama ini memang Rara tahu kalau orangtuanya beda agama. Tapi, Rara kira Vasty sudah memilih menjadi muslim. Habis, dia juga nggak pernah cerita banyak ke Rara," kataku sambil merebahkan kepalaku di pangkuan ibu.

(Sambodja, 2007:25)

Kutipan di atas jelas menggambarkan kekagetan Rara tentang agama sebenarnya yang dianut Vasty. Meskipun begitu, Rara tidak lantas langsung memutuskan persahabatannya dengan Vasty yang berbeda agama. Rara tetap menganggap Vasty sebagai sahabatnya. Hal ini bisa dibuktikan dari kekhawatiran Rara yang tidak mengetahui kabar Vasty seharian penuh. Meskipun saat itu Rara sudah mengetahui bahwa Vasty adalah seorang Kristiani.

c. Ibu Rara menasehati Vasty melalui Rara dengan mengutip ayat toleransi dari Al-Quran

Sikap toleransi Ibu Rara terlihat saat beliau memberikan nasehat untuk Vasty melalui Rara. Lebih dari itu, Ibu Rara juga mengutip Ayat toleransi dari Al-Quran, untuk memahamkan kepada Rara bahwa Islam sangat menjunjung tinggi toleransi. Hal ini juga merupakan gambaran tentang kebijaksanaan yang dimiliki oleh Ibu Rara.

"Ra, Allah nggak pernah memaksa umat-Nya dalam menyembah-Nya. la hanya menunjukkan jalan yang Dia ridhoi. Kan ada di Al-quran. Lakum diinukum wa liyadiin. Bagimu agamamu dan bagiku agamaku. Vasty harus memilih. Bukan karena siapa-siapa. Tapi karena dia percaya pada Tuhan."

(Sambodja, 2007:26)

Kutipan di atas memberikan gambaran tentang besarnya toleransi yang ditunjukkan Islam sebagai agama rahmat. Kutipan di atas juga menjelaskan tentang pengajaran yang diberikan Ibu Rara kepada Rara agar dapat menerima perbedaan-perbedaan yang terjadi dengan tetap memperhatikan batasan-batasannya.

\section{Kesediaan Bertanggung Jawab}

Kesediaan bertanggung jawab merupakan sikap dan perilaku seseorang untuk melaksanakan tugas dan kewajiban yang seharusnya dia lakukan, terhadap diri sendiri, masyarakat, lingkungan (alam, sosial, dan budaya), negara dan Tuhan Yang Maha Esa. Nilai moral tentang kesediaan bertanggung jawab merupakan salah satu nilai moral yang dominan. Hal ini dikarenakan hampir setiap tokoh mengemban atau membawakan nilai moral ini.

"Tadinya gue pikir gue masih bisa membujuk mereka supaya membatalkan perceraian mereka, tapi semalam mereka bertengkar lagi. Gue nggak tahu mesti gimana lagi, Ra! Gue nggak mau mereka cerai. Cuma mereka yang gue punya, Ra." Vasty berusaha menyeka air matanya."

(Sambodja, 2007:22)

Kutipan di atas menjelaskan tentang kesediaan bertanggung jawab yang dimiliki Vasty sebagai seorang anak. Sebagai seorang anak yang sudah dewasa, Vasty memiliki kewajiban untuk memberikan masukan semampunya kepada orangtuanya yang sedang konflik.

Nilai moral tentang kesediaan bertanggung jawab yang dimiliki Vasty juga tergambar pada kutipan berikut.

"Tadi di mobil Vasty cerita. Dia memang nggak pernah sungguh-sungguh menjalankan salah satu agama orangtuanya. Setiap tahun pasti ia ikut puasa bareng ayahnya, begitu juga kalau natal. Dia pasti ikut misa bersama ibunya di gereja. Menurutnya sama saja. Dia tetap bersyukur kepada Tuhan atas nikmat yang dia terima. Menurut dia, itu yang penting," ceritaku pada ibu.

(Sambodja, 2007:23)

Kutipan di atas merupakan gambaran nilai moral tentang kesediaan bertanggung jawab yang dimiliki Vasty. Sebagai seorang manusia Vasty memiliki kewajiban untuk selalu bersyukur kepada Tuhan atas segala ketentuan yang telah ditetapkan dalam kehidupannya. Manusia harus senantiasa

Dedi Febriyanto, Suryani 
Kesediaan bertanggung jawab juga tampak pada sosok Silka dalam cerpen lbu. Bentuk tanggung jawab Silka dalam cerpen ini bisa dilihat pada kutipan berikut.

Ada kuliah yang harus ku hadiri, maka aku diantar bapak ke kampus. Seusai kuliah aku pulang ke kos. Aku tidak kembali ke rumah sakit karena aku ada kuliah keesokan harinya.

(Sambodja, 2007: 41)

Pada kutipan diatas digambarkan bahwa Silka tidak melupakan kewajibannya sebagai seorang mahasiswi, meski di sisi lain Silka harus merawat Ibunya yang sedang sakit parah.

Nilai moral tentang kesediaan bertanggung jawab juga tergambar secara tersirat dalam cerpen Protemus \& Claius. Kesediaan bertanggung jawab digambarkan dengan serangkaian cerita yang bertolak belakang dengan nilai moral ini. Artinya, dalam cerpen ini yang ada adalah ketidak-sediaan bertanggung jawab. Sikap tersebut tergambar pada sosok Claius yang melakukan tindakan bunuh diri karena merasa hidupnya tidak berguna lagi tanpa kehadiran Protemus.

la menyudut pada kesendirian, hidup dalam birai-birai kesepian. Melamunkan wujud-wujud tak kasat yang selalu membercak di matanya. la memanggil Protemus dalam ruang hampa. Terus...

Dalam lemari kotak dua pintu terbuat dari kayu, di sana Claius menyayat urat nadinya dengan belati. la merasakan ketidakbergunaan dalam setiap kejut jantungnya dan langkah hidupnya. Di sampingnya berbaring buku yang selalu ia baca sebelum saudara kembarnya tertidur, Reincarnation. la mencoba untuk tidak menjadi sampah, dan menemui Protemus yang entah di alam mana.

\section{Mungkin ini jalanku menujumu}

(Sambodja, 2007:113)

Kutipan di atas menggambarkan ketidakberdayaan Claius setelah ditinggal pergi Protemus untuk selamanya. Seharusnya Claius bisa bangkit dari keterpurukannya dan menjalani kehidupannya dengan normal. Itu sudah menjadi tanggung jawabnya karena ia telah dianugerahi oleh Tuhan kesempatan hidup lebih lama. Tapi yang terjadi justru sebaliknya, Claius melakukan tindakan bunuh diri dengan menyayat urat nadinya sendiri dengan belati. Claius tidak sadar bahwa yang dilakukannya sama saja dengan ia melemparkan dirinya sendiri ke dalam lembah kenistaan.

\section{Keberanian Moral}

Keberanian moral merupakan sikap yang menunjukkan diri dalam tekad untuk tetap mempertahankan sikap yang telah diyakininya sebagai kewajiban meskipun tidak disetujui atau secara aktif dilawan oleh lingkungan (Suseno, 2005:147). Nilai moral tentang keberanian moral dalam cerpen ini dapat dilihat pada kutipan berikut.

"Semalam gue bilang kalau gue akan ikut tinggal sama nyokap dan juga akan ikut agama Kristen kayak nyokap. Setelah gue bilang begitu, mereka bertengkar hebat, Ra! Kalau udah begitu, gue bingung Ra."

(Sambodja, 2007:23)

Kutipan di atas menggambarkan keberanian moral yang dimiliki Vasty. Keberaniannya mengungkapkan isi hati berkenaan dengan agama yang dipilihnya. Vasty tetap menyampaikan kejujuran hatinya meskipun pada akhirnya kedua orangtuanya bertengkar hebat karena keputusannya.

Gambaran keberanian moral juga terlihat di dalam cerpen Protemus \& Claius. Nilai moral tersebut bisa dilihat melalui kutipan berikut.

Kalender menunjukkan tanggal 9 September. Mereka telah menghitung hari dengan melingkari angka-angka. Sebulan lagi Persiapan mereka menuju operasi pembelahan kepala. Sewaktu-waktu pertanyaan batin perihal kematian mengitari kepala mereka. Protemus dan Claius selalu mengendapkan pertanyaan-pertanyaan itu dan melelehkannya dalam keoptimisan.

(Sambodja, 2007:105)

Kutipan di atas menjelaskan tentang waktu pelaksanaan operasi pembelahan kepala yang sudah mereka rencanakan jauh-jauh hari. 


\section{Religiositas}

Religiositas merupakan nilai moral yang berkaitan erat dengan kesalehan seseorang, ketaatan manusia terhadap agamanya. Nilai moral tentang religiositas dalam cerpen ini diperlihatkan dalam kutipan berikut.

"Ra, Allah nggak pernah memaksa umat-Nya dalam menyembah-Nya. la hanya menunjukkan jalan yang Dia ridhoi. Kan ada di Al-quran. Lakum diinukum wa liyadiin. Bagimu agamamu dan bagiku agamaku. Vasty harus memilih. Bukan karena siapa-siapa. Tapi karena dia percaya pada Tuhan."

(Sambodja, 2007:26)

Kutipan di atas menggambarkan Nilai moral religiositas yang melekat dalam diri lbu Rara. Kereligiusan Ibu Rara. Pada kutipan tersebut digambarkan bahwa Ibu Rara memberikan tanggapan kepada Rara dengan mengutip ayat toleransi dalam Al-Qur'an. Sikap Ibu Rara ini sangat penting dan ini merupakan cerminan kesalehan Ibu Rara. Ibu Rara memahami bahwa Islam sebagai agama rahmat sangat menjunjung tinggi toleransi dalam bergama. Islam tidak pernah memaksakan kehendak beragama. Inilah sebenarnya nasehat tersirat yang hendak disampaikan Ibu Rara kepada anaknya.

Nilai religiositas juga tergambar beberapa kali di dalam cerpen Ibu. Hal ini bisa dilihat melalui kutipan berikut.

Semalaman keadaan Ibu tetap sama. Napasnya berat, mulutnya terbuka, kesadarannya hilang. Aku dan Adikku meninggalkan Ibu hanya untuk sholat.

(Sambodja, 2007: 44)

Nilai religius pada kutipan di atas terletak pada kepatuhan Rara dan Adiknya terhadap kewajiban yang ditetapkan oleh Allah bagi orang Islam. Kewajiban tersebut masih tetap dilaksanakan meskipun pada kondisi dan situasi yang sulit, menjga Ibundanya yang sakit parah. Namun semua itu tidak membuatnya terlena dan melupakan kewajibannya sebagai orang Islam.

Nilai religius lainnya juga tergambar pada kutipan berikut ini yang menjelaskan tentang tradisi keislaman Ahlusunah Annahdliyah

Setelah aku agak tenang, kulihat sekeliling ruangan. Banyak sekali orang yang berkumpul di dalam ruangan itu. Adik-adik Bapak, saudara lbu, beberapa tetanggaku, semua berwajah sendu. Beberapa tetanggaku dan teman-teman Ibu membacakan surat Yasin. Tidak ada lagi yang bisa kami lakukan selain berdoa mohon Ibu dilapangkan jalannya.

(Sambodja, 2007: 44)

Kutipan di atas menggambarkan nilai moral religiositas yang tercermin dalam sebuah tradisi yang dilakukan oleh keluarga dan tetangga sang lbu yang selalu berdoa dan membacakan Yasin untuk sang lbu. Tradisi tersebut merupakan salah satu usaha terakhir yang bisa dilakukan. Memohon ketetapan terbaik-Nya untuk sang Ibu.

\section{Bekerja Keras}

Bekerja keras merupakan perilaku yang menunjukkan upaya sungguh-sungguh dalam mengatasi berbagai hambatan atau masalah dalam kehidupan, serta dapat menyelesaikannya dengan sebaik-baiknya. Nilai moral tentang kerja keras dalam cerpen lbu dilekatkan pada sosok lbu yang terjangkit kanker beserta keluarga. Hal ini dikarenakan, sikap bekerja keras atau usaha maksimal tidak hanya dilakukan oleh sosok lbu saja, melainkan seluruh keluarga besarnya. Hal ini bisa dilihat pada kutipan berikut.

Ibu memilih pengobatan alternatif. Apapun jenisnya, Ibu mencobanya tanpa henti. Kami tidak kaya, namun rupiah tidak menjadi masalah. Kesembuhan Ibu adalah yang paling utama.

Ibu tidak berhenti berusaha, sel-sel kanker pun tidak berhenti bekerja.

(Sambodja, 2007:39)

Kutipan di atas menggambarkan tentang usaha yang dilakukan sang ibu untuk kesembuhan dirinya. la selalu mencoba pengobatan alternatif tanpa henti. Keluarganya memang tidak kaya, tapi uang bukanlah masalah asal lbu bisa kembali sehat. berikut.

Selain itu, wujud usaha atau kerja keras yang dilakukan keluarga juga bisa dilihat pada kutipan

Kami membawa lbu ke rumah sakit di ujung selatan Jakarta yang lebih berkesan seperti hotel 
Pada kutipan di atas jelas terlihat, demi kesembuhan si lbu, pihak keluarga sampai membawanya ke rumah sakit yang mewah agar sang lbu bisa nyaman tinggal di dalamnya dan dapat mempercepat kesembuhannya.

\section{Optimisme}

Optimis merupakan sikap yang penuh pengharapan. Meyakini dengan sepenuh hati bahwa segala sesuatunya akan berakhir dengan baik. Optimis merupakan sikap positif yang harus ditanamkan pada diri manusia. Nilai moral tentang optimisme di dalam cerpen Protemus dan Claiusterdapat pada kutipan berikut.

Kalender menunjukkan tanggal 9 September. Mereka telah menghitung hari dengan melingkari angka-angka. Sebulan lagi Persiapan mereka menuju operasi pembelahan kepala. Sewaktu-waktu pertanyaan batin perihal kematian mengitari kepala mereka. Protemus dan Claius selalu mengendapkan pertanyaan-pertanyaan itu dan melelehkannya dalam keoptimisan.

(Sambodja, 2007:105)

Kutipan di atas menggambarkan tentang kekhawatiran yang terkadang muncul dibenak Protemus dan Claius berkenaan dengan bayang-bayang kematian yang kelak akan menghampiri salah satu diantara mereka. Namun, kekhawatiran tersebut bisa dihilangkan dengan membangun sikap optimisme dalam diri. Mereka percaya bahwa semua akan berakhir dengan baik.

Sikap optimisme juga terlihat jelas melekat dalam diri dua saudara kembar abnormal, Protemus dan Claius. Hal ini tergambar pada kutipan berikut.

\footnotetext{
"Aku sudah baca riwayat dokter dan rumah sakit itu, Claius! Kesuksesan mereka dalam menangani pembelahan kembar siam, lima banding dua," ucap Protemus sambil menyiapkan perjalanan menuju kampus.

"Ya ya... aku selalu optimistis akan hal itu!"
}

(Sambodja, 2007:105-106)

Keoptimisan pada kutipan di atas tergambar saat Claius mengatakan dengan pasti bahwa dia sangat optimis operasi yang akan dijalaninya dengan Protemus akan berjalan dengan lancar.

\section{Kejujuran}

Nilai moral tentang kejujuran yang terdapat didalam cerpen ini disampaikan oleh pengarang melalui sikap tokoh yang bertentangan dengan kejujuran itu sendiri. Artinya, kejujuran tersebut disampaikan pengarang secara tersirat. Sosok Protemus maupun Claius dalam cerpen ini tidak mau berterus terang tentang kerelaannya melepas Redha, wanita yang dicintai keduanya. Hal ini bisa dilihat ketika mereka membahas tentang Redha, yang terjadi hanyalah sebuah cekcok, adu mulut, tak pernah ada yang mau mengalah. Tetapi yang sebenarnya, di lubuk hati yang paling dalam, tersimpan sebuah rasa penuh kerelaan jika seandainya Redha dicintai atau mencintai salah satu diantara keduanya. Hal ini bisa dilihat pada kutipan surat yang ditulis Claius dan juga Protemus tanpa sepengetahuan keduanya, dan surat itu sama-sama ditujukan kepada Redha.

Claius sempat memberikan pesan kepada Redha melalui sepucuk surat menjelang operasi besar itu dimulai. Surat itu ia tulis tanpa sepengetahuan Protemus.

... Dan kau pasti telah paham isi hatinya. Aku tak sanggup meninggalkannya, sampai benarbenar kematian tandang padaku. Tolong berikan cintamu padanya setulus kau kau mencintai anggrek-anggrek purnama. Kelak sisa darahku yang mengering di otaknya akan menjadi pengiring hidup kalian. Terima kasih, Redha.

(Sambodja, 2007:111-112)

Pada kutipan di atas, ketulusan dan kerelaan Claius sangat jelas terlihat. Claius sangat menyayangi dan menghargai Protemus yang mencintai Redha. Karena itulah Claius dengan penuh permohonan kepada Redha agar ia mau mencintai Protemus dengan setulus hatinya.

Di sisi yang lain, Protemus pun sempat melayangkan surat kepada Redha. Isi surat tersebut bisa dilihat pada kutipan berikut:

Taburkanlah bunga di atas makamku kelak, jika aku mati tanpa dapat mengucapkan serpih kata cinta untukmu. Dan berikanlah harapan yang menggumpal dalam lirihnya. Cintai Claius, 
Redha.

Sama halnya dengan Claius, Protemus pun dengan penuh pengharapan meminta kepada Redha agar dia bersedia mencintai Claius dengan setulus hatinya.

Keterkaitan Antar Unsur Intrinsik Kumpulan Cerpen Tuhan buat Vasty Suntingan Asep Sambodja

Keterkaitan antar unsur dalam sebuah karya sastra merupakan suatu keniscayaan. Hal ini dikarenakan keterkaitan antar unsur akan menjadikan karya sastra memiliki kualitas dan daya tarik yang kuat. Secara umum, keterkaitan antar unsur yang terdapat di dalam kumpulan cerpen Tuhan buat Vasty meliputi keterkaitan antara alur/plot, latar, tokoh dan penokohan, latar/setting, amanat serta sudut pandang yang terikat dengan tema sebagai dasar dalam pembuatan karya sastra.

Tema yang terdapat di dalam cerpen berkutat pada permasalahan keluarga, termasuk di dalamnya konflik anak dan orang tua, penderitaan seorang lbu menghadapi sakit kanker, sampai konflik saudara kembar yang terlahir abnormal. Melalui tema-tema tersebut kemudian pengarang membuat cerita dengan menggunakan alur kronologis. Alur tersebut terjadi dari peristiwa-peristiwa yang dijalankan oleh tokoh-tokoh. Tokoh-tokoh ini mempunyai watak yang berbeda antara satu dengan yang lain.

Cerita yang dibawakan oleh tokoh-tokoh tersebut kemudian ditopang oleh sudut pandang yang digunakan pengarang. Tokoh cerita memerankan suatu peristiwa berlandaskan latar cerita. Amanat atau pesan-pesan moral pun akhirnya tergambar dari serangkaian peristiwa dan tingkah laku para tokoh. Hubungan tema dengan unsur-unsur lainnnya secara garis besar bisa dicontohkan pada kutipan berikut.

"Ra, gue bingung...," ia menutupi wajahnya dengan kedua tangannya. Aku semakin bingung. Kenapa sih Vasty?

"Bokap Nyokap gue mau cerai. Lo tahu kan selama ini agama mereka beda. Sekarang mereka tanya masalah pilihan agama gue. Gue nggak mau bikin salah satu dari mereka sedih atau kecewa.

(Sambodja, 2007:22)

\begin{abstract}
"Ya ampun Vas, kenapa baru cerita?" tanyaku sambil memeluk Vasty yang masih menangis tersedu-sedu.

"Tadinya gue pikir gue masih bisa membujuk mereka supaya membatalkan perceraian mereka, tapi semalam mereka bertengkar lagi. Gue nggak tahu mesti gimana lagi, Ra! Gue nggak mau mereka cerai. Cuma mereka yang gue punya, Ra." Vasty berusaha menyeka air matanya. Aku menyodorkan sebungkus tissue kepadanya."
\end{abstract}

(Sambodja, 2007:22)

Kutipan di atas menjelaskan tentang permulaan Vasty mencurahkan permasalahannya kepada Rara yang selama ini dipendamnya seorang diri. Melalui kutipan tersebut, bisa dilihat bahwa untuk memunculkan tema diperlukan interaksi tokoh satu dengan tokoh yang lain. Gerak-gerik tokoh juga tidak terlepas dari latar. Pada kutipan di atas, kantin merupakan latar yang tergambar jelas sebagai tumpuan dimana peristiwa yang diperankan tokoh terjadi. Cara pengarang membawakan cerita pun terlihat jelas pada kutipan di atas. Sudut pandang melibatkan tokoh tambahan bernama Rara. Sudut pandang pengarang selalu berjalan beriringan dengan peristiwa-peristiwa yang diperankan tokoh. Artinya sudut pandang berkaitan erat dengan tokoh cerita.

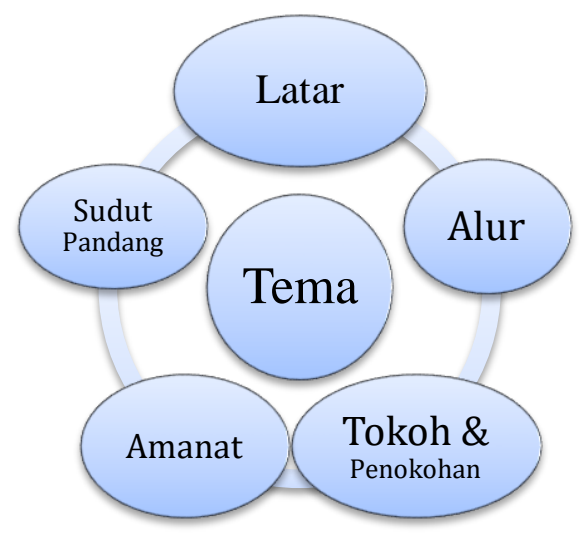

Gambar 1: Bagan Keterkaitan Antar Unsur intrinsik 
Peristiwa-peristiwa dalam cerita yang dimunculkan tokoh cerita terjadi secara kronologis. Artinya cerita menggunakan pengaluran maju. Unsur-unsur yang membentuk satu kesatuan tersebut juga membawakan sebuah pesan-pesan moral, baik secara langsung atau tersirat untuk para pembaca. Pesan-pesan moral tersebut khususnya dapat dilihat melalui tingkah laku tokoh yang didukung unsur-unsur lainnya. Berdasarkan pemaparan di atas, dapat disimpulkan bahwa unsurunsur dalam karya sastra memiliki hubungan yang saling terikat, membentuk suatu kesatuan makna yang utuh dalam sebuah karya sastra, khususnya cerpen.

\section{Keterkaitan Unsur Intrinsik dengan Nilai Moral dalam Kumpulan Cerpen Tuhan buat Vasty Suntingan Asep Sambodja}

Nilai moral merupakan salah satu hal yang ingin disampaikan oleh pengarang kepada pembaca. Nilai moral dalam karya sastra secara umum dapat diketahui melalui penokohan tokoh cerita. Namun tidak menutup kemungkinan bahwa nilai moral juga bisa tergambar jelas di dalam tema cerita dan amanat. Sebagaimana yang telah dijelaskan sebelumnya, untuk memunculkan tema cerita, pengarang memerlukan unsur-unsur cerita lainnya, mulai dari tokoh cerita, latar, sampai sudut pandang. Begitu juga dengan kedirian tokoh cerita, kedirian tokoh tidak akan dapat tergambar sempurna jika tidak diiringi dengan latar cerita.

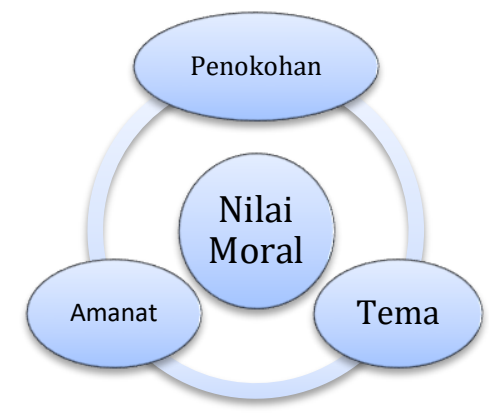

Gambar 2: Bagan Keterkaitan Unsur Intrinsik dengan Nilai Moral

Berdasarkan penjelasan tersebut, secara tidak langsung untuk memunculkan nilai-nilai moral secara utuh diperlukan kesatuan semua unsur dalam cerpen. Unsur-unsur dalam karya sastra diibaratkan sebagai wadah yang digunakan untuk menampung muatan. Muatan dalam karya sastra berwujud makna cerita. Adapun salah satu bagian dari makna cerita tersebut adalah nilai moral. Hubungan keterkaitan unsur intrinsik dengan nilai moral dapat digambarkan sebagai berikut.

\section{PENUTUP}

Berdasarkan analisis yang telah dilakukan, dapat disimpulkan bahwa tema yang diangkat dalam ketiga cerpen yang diteliti berkutat permasalahan keluarga. Kumpulan cerpen Tuhan buat Vasty bertemakan permasalahan keluarga yang bermacam-macam. Permasalahan itu sendiri dipicu oleh keegoisan tokoh sampai takdir yang kurang berpihak. Tema cerita sendiri dibentuk oleh unsur cerita yang lainnya. Unsur cerita tersebut meliputi tokoh dan penokohan, alur, sudut pandang sampai amanat. Seluruh unsur tersebut membentuk suatu jalinan yang memiliki hubungan timbal balik. Seluruhnya tidak bisa dipisahkan karena masing-masing unsur memiliki fungsi. Adapun buah dari hubungan antar unsur adalah terbentuknya makna cerita yang utuh. Salah satu makna cerita tersebut adalah nilai-nilai moral. Nilai moral dalam cerpen ini secara umum dibentuk oleh unsur tokoh dan penokohan. Nilai-nilai moral yang terkandung di dalam cerpen meliputi, religiositas, kepedulian sosial, kejujuran, keberanian moral, bekerja keras, dan optimisme.

\section{UCAPAN TERIMAKASIH}

Ucapan terimakasih ditujukan kepada ketua STKIP Nurul Huda dan TIM peneliti.

\section{DAFTAR PUSTAKA}

Ayu M.Y. 2013. Analisis Struktural dan Nilai Moral Cerpen Te Bukuro Wo Kai Ni Karya Niimi Nankichi. Skripsi. Tidak Diterbitkan. Fakultas Ilmu Budaya. Universitas Diponegoro: Semarang.

Depertemen Agama RI. 2002. Al-Qur’an dan Terjemahnya. Jakarta: Mahkota Surabaya.

Hafnita Nugraheny. 2014. Kajian Strukturalisme Objektif pada Novel Tretes Tintrim Karya Suparto Brata. Skripsi. Tidak Diterbitkan. Fakultas Bahasa dan Seni. Universitas Negeri Yogyakarta:

Yogyakarta.

Dedi Febriyanto, Suryani 
Jabrohim. 2015. Teori Penelitian Sastra. Yogyakarta: Pustaka Pelajar.

Linda Wijaya. 2015. Upacara Adat Kematian Masyarakat Tionghoa dalam perspektif Agama Kristen Protestan pada Yayasan Golgota Gereja Kristen Kalimantan Barat di Pontianak. Skripsi. Tidak Diterbitkan. Fakultas Hukum. Universitas Tanjungpura: Pontianak.

Mustamar, Marzuqi. 2014. Dalil-dalil Praktis Amaliah Nahdliyah. Surabaya: Muara Progresif.

Nurgiyantoro, Burhan. 2015. Teori Pengkajian Fiksi. Yogyakarta: Gadjah Maja University Press.

Ratna, Nyoman Khuta. 2015. Teori, Metode, dan Teknik Penelitian Sastra. Yogyakarta: Pustaka Pelajar.

Rohmadi, Muhammad \& Yakub Nasucha. 2017. Dasar-Dasar Penelitian Bahasa, Sastra, dan Pengajaran. Surakarta: Pustaka Briliant.

Sambodja, Asep. 2007. Tuhan buat Vasty. Jakarta: Buku Pop.

Sri Wahyuni. 2011. Perkawinan Beda Agama di Indonesia dan Hak Asasi Manusia. Jurnal Perbandingan Mazhab dan Hukum. 1 (1): 135-136.

Sri W.S. 2005. Nilai-Nilai Moral dalam Cerita Ramayana Karya Sunardi D.M.: Analisis Tokoh, Penokohan, Alur, Latar, dan Tema dan Relevansinya sebagai Bahan Pembelajaran Sastra untuk SMA Kelas X. Skripsi. Tidak Diterbitkan. Fakultas Keguruan dan IImu Pendidikan. Universitas Sanata Dharma: Yogyakarta.

Sugiono. 2017. Metode Penelitian Pendidikan: Pendekatan Kuantitatif, Kualitatif, dan R\&D. Bandung: Alfabeta.

Suseno, Frans Magnis. 2005. Etika Dasar: Masalah-Masalah Pokok Filsafat Moral. Jakarta: Pustaka Filsafat.

Tim Penyusun Pusat Kamus. 2007. Kamus Besar Bahasa Indonesia. Jakarta: Balai Pustaka.

Zakiyah Yulianti, Rusdiana A. 2014. Pendidikan Nilai: Kajian Teori dan Praktik di Sekolah. Bandung: Pustaka Setia. 